\title{
AS DETERMINAÇÕES BIOLÓGICA E SOCIAL DA DOENÇA: UM ESTUDO DE ANEMIA FERROPRIVA *
}

\author{
Ignez Salas Martins * \\ Augusta Thereza de Alvarenga ** \\ Amaldo Augusto Franco de Siqueira * * \\ Sophia Cornbluth Szarfarc * * \\ F ernião Dias de Lima ****
}

MARTINS, I.S. et al. As determinaçōes biológica e social da doença: um estudo de anemia ferropriva.

Rev.Saúde públ., S.Paulo, 21 : 73-89, 1987.

RESUMO: Buscou-se caracterizar os diferentes níveis de determinação da anemia carencial, enquanto fenômeno de saúde pública, a partir de algumas das relaçōes biológicas e sociais definidoras desse processo saúde-doença. Articulando a análise dos processos específicos de determinada população de gestantes aos processos gerais próprios da metrópole paulistana, pôde-se observar como as condiçôes para a ocorrência da anemia ferropriva estão atreladas às condiçōes sociais e econômicas, de classe, seja pelas deficiências qualitativas e quantitativas da dieta, seja pela precariedade de saneamento ambiental, condiçōes essas típicas das áreas habitadas pelas camadas sociais mäis baixas. Focalizando um outro nível hierárquico das determinações, a análise dessas carências foi remetida, tendo em vista os processos biológicos singulares, ao conceito de vulnerabilidade orgânica tomado como articulador das características definidoras de grupos biológicos específicos frente aos riscos diferenciais de adoecer e morrer por "causas" ou processos mórbidos particulares, riscos esses atrelados às próprias condições de classe. Caracterizando os determinantes últimos dessa carência em função do baixo nível de consumo do que se convencionou chamar de "bens fundamentais", a análise buscou apreender elementos da realidade paulistana capazes de fornecer subsídios para o estabelecimento de possíveis "níveis críticos de consumo", isto é, determinada condição de vida abaixo da qual os indivíduos, (no caso as gestantes adscritas a grupos sociais específicos) estariam inscritos em situações particulares, simultaneamente de naturezas orgânica e social, "determinantes" dos níveis de risco à doença carencial. Focalizou-se a trajetória existente entre as condiçōes de normalidade e de anemia, em termos de processo cuja fase intermediária entre a doença e o estado de normalidade foi representada pela deficiência de ferro sem anemia, entendida como fase subclínica. Nesta, esses três momentos do processo foram analisados em função das condições sócio-econômicas do grupo considerado. Articulando categorias de renda consideradas, em função do processo de análise, como incompatíveis com as possibilidades objetivas de aquisição dos "bens fundamentais" definidos como mínimos, pôde-se caracterizar determinada condição social e econômica a partir da qual a anemia ferropriva teria, por hipótese, maior probabilidade de incidência, considerados os vários processos em jogo, quer de natureza social, quer de natureza biológica.

UNITERMOS: Saúde e doença. Anemia ferropriva, incidência. Gravidez. Fatores socioeconômicos. Classe social. Dieta. Saneamento urbano. Risco.

\section{INTRODUÇÃO}

E sobejamente conhecida, a partir da literatura especializada, a grande prevalência da anemia carencial em todas as partes do mundo, notadamente em suas regioes mais pobres $9,12,20,26,27,33,42,45$. Embora em nosso meio não se disponha de dados sobre o país como um todo, estudos específicos têm revelado sua importância em termos de saúde pública como, por exemplo, os trabalhos de Szarfarc50 que verificou, para o Estado de São Paulo, 31,1\% de anêmicas dentre a população de gestantes atendidas em centros de saúde. Em meados da década de 70, essa mesma autora observou para um grupo de parturientes de baixo nível sócioeconômico, que deram à luz em dado hospital da capital, um valor de $52,7 \%$ de anemia 49 .

Tendo em vista que a ocorrência da anemia se traduz, ao nível do organismo humano, na incapacidade do tecido eritropoiético em manter uma concentração normal de hemoglobina, devido ao suprimento inadequado de ferro, $o$ fato a considerar é que a anemia, representada pela baixa concentração de hemoglobina $e$, no entanto, a manifestação última de uma carência prévia que provavelmente provocou a exaustão das reservas de ferro do organismo.

- O presente trabalho é uma versão modificada do capítulo IV da tese de livre docência intitulada "A dimensão bioló. gica e social da doença", apresentada à Faculdade de Saúde Pública da USP, por Ignez Salas Martins.

** Departamento de Nutrição da Faculdade de Saúde Pública da Universidade de São Paulo - Av. Dr. Arnaldo, 715 - 01255 - São Paulo, SP - Brasil.

* * Departamento de Saúde Materno-Infantil da Faculdade de Saúde Pública da Universidade de São Paulo.

*.* Departamento de Epidemiologia da Faculdade de Saúde Pública da Universidade de São Paulo. 
MARTINS, I.S. et al. As determinaçōes biológica e social da doença: um estudo de anemia ferropriva. Rev. Saúde públ.,

Tendo em vista. a perspectiva de trabalho em saúde pública, tanto ao nível da teoria quanto da prática, é fundamental avançar na idéia de que, embora essa carência de ferro seja, nessa expressão última, caracteristicamente um problema orgânico, a questão da "explicação" de sua ocorrência não se reduz a essa dimensão, ou seja, aos processos gerados por "causas" que se localizam no interior do organismo humano, como a deficiência de consumo e absorção de alimentos e/ou a espoliação desses mesmos nutrientes. Assim, para conhecer esse fenômeno, na sua totalidade, é necessário ir mais além considerando, igualmente, a realidade exterior ao organismo humano, na qual o indivíduo se insere participando de processos sociais específicos, também determinantes, numa outra dimensão, da carência de ferro.

Dentro dessa linha de preocupação teórico-metodológica, a hipótese central que se delineia é a de que a busca de "explicação" da anemia carencial implica recuperar os diferentes níveis de determinação do fenômeno, níveis esses relativos a relações biológicas e sociais definidas no processo saúde- doença. Com isto se pretende dizer que o fato não se circunscreve aos resultados de processos gerados nos organismos dos indivíduos, vistos isoladamente, mas se constitui em resposta biológica a impulsos exteriores que atuam sobre estes, manifestando-se num processo característico de ação recíproca, organismo-meio ambiente, a partir do qual se evidencia que o homem não adoece só mas sim em função das relaçðes estruturadas que mantém com a natureza e com os demais homens. Com isto defende-se a idéia de que reduzir o estudo da anemia ferropriva a uma manifestação presente, unicamente a nivel do organismo humano representa, sobretudo, descaracterizar-lhe a natureza de fenômeno coletivo, estruturalmente articulado e resultante, portanto, de uma manifestação concreta do próprio processo histórico-social no qual os indivíduos se inscrevem sob relaçסes sociais determinadas.

Cumpre lembrar que, embora seja possivel "determinar", a partir de uma análise "multicausal", um elenco de variáveis nomeadas quer como "causas", quer como "fatores de risco", tanto de caráter biológico quanto de natureza social, restringir a questão do conhecimento da anemia ferropriva a esse tipo de abordagem implica limitar o alcance da explicação do fenômeno a nível da realidade social que o define de maneira própria. Isto porque este tipo de abordagem, típica das formas de explicação buscadas classicamente pela Epidemiologia para os estudos da morbidade e da mortalidade, é criticável, do ponto de vista teórico-metodológico, por não permitir, na relação teoria e prática, quer a apreensão dos diferentes niveis de determinação das diferentes "causas" ou "fatores de risco" (como indicativos dessas "causas"), quer a diferenciação dos níveis de determinação destes em função de sua natureza biológica ou social. A isto equivale dizer que o pressuposto básico dessa abordagem é o de que todas as variáveis, muitas vezes selecionadas de maneira arbitrária pelo observador, atuam, em função dos pressupostos metodológicos do modelo, de maneira homogênea, portanto, não determinada. *

$O$ embasamento para o estudo da anemia ferropriva a partir dessas proposiçðes tem relação quer com a proposta defendida por Breilh6,7, quer com o argumento defendido por Laurell 31,32 de que cada formação social apresenta um perfil patológico típico. Este conceito, que permite relacionar, a nível do conhecimento existente, estruturas epidemiológicas de morbidade e mortalidade a estruturas sociais definidas, parece sustentar, de maneira objetiva, a existência de processos particulares definidores dos vínculos presentes entre o processo social e o processo biológico saúde-doença, processos esses tidos ao mesmo tempo como sociais e biológicos. * $\mathrm{O}$ modo da autora entender a relação entre ambos os processos permite apontar, por um lado, o fato de que o social tem uma hierarquia distinta do biológico na determinação do processo saúde. - doença e nega, por outro, a concepção bastante generalizada de que o social desencadeia unicamente processos biológicos imutáveis e a-históricos. Além disso permite considerar o caráter social do próprio processo biológico, em sua especificidade.

Esse tratamento teórico do problema ganha relevância na medida em que permite avançar na explicação de como cada formação social cria determinado padrão social de desgaste e reprodução biológica relativo à doença. Esta passa a se expressar não em termos de entidades patológicas particulares mas através de uma ampla soma de padecimentos específicos mais ou menos bem definidos e categorizados pelo conhecimento especializado ${ }^{* * *}$; nomeada como "perfil patológico", permite recuperar a manifestação da determinaç̃̃o social em função da qual a

- Para uma análise da questão veja-se, por exemplo, os trabalhos de Breilh6,7.

* Muito embora a assunção de que toda e qualquer patologia tenha necessariamente uma determinação social, de caráter universal e, portanto, seja passível de gerar, ao nível do conhecimento, uma polêmica tanto de natureza epistemológica, quanto ontológica, o fato a considerar é que no caso da anemia carencial (ferropriva) esta hipótese é altamente sustentável em função das evidências empíricas.

$\therefore$ Em função do recurso metodológico empregado pela autora 32 "esta ampla soma de padecimentos específicos mais ou menos definidos" são aqueles representados, no caso, pela Classificação Internacional de Doenças. 
MARTINS, I.S. et al. As determinações biológica e social da doença: um estudo de anemia ferropriva. Rev. Saúde públ., S.Paulo, 21 : 73-89, 1987.

doença é gerada. Como bem exemplifica Laurell 32 , se o modo concreto de trabalhar, cujo caráter social é evidente, é também, ao mesmo tempo biológico, pois envolve em determinada atividade neuromuscular, metabólica e assim por diante, outro exemplo típico pode ser o comer, uma vez que o que se come, e como se come, são fatos sociais que tem sua contrapartida biológica.

Tendo em vista que, em termos das determinações mais gerais, o processo saúde-doença articula-se ao modo como o homem se apropria da natureza em um dado momento 32 e considerando que essa apropriação se realiza por meio do processo de trabalho baseado em determinado desenvolvimento das forças produtivas e relações de produção, o fato é que, sendo as relações de classe aquelas determinantes das articulaçóes dos processos específicos de reprodução social, senso lato, é sobre elas que passa a repousar, portanto, o foco central de análise das açoes recíprocas existentes entre o processo social e o processo saúde-doença numa dada formação social.

A importância de se considerar na Saúde Pública a problemática da saúde e da enfermidade não de forma isolada mas no contexto de um sistema produtivo mais amplo, gerador de processos específicos determinantes da mesma, fica evidente no caso da anemia ferropriva. Observa-se, de maneira específica, que as condiçōes para a ocorrência dessa carência estão atreladas às condições sociais e econômicas, características das situações de classe (às quais estão adscritos os indivíduos), seja pelas deficiências qualitativas e quantitativas da dieta, seja pela precariedade de saneamento ambiental. Isto se sustenta, por um lado, quando se constata que tanto a deficiência de consumo como a de absorção são devidas à inadequação qualitativa e quantitativa da dieta. Este fato se refere não apenas à quantidade de ferro ingerida mas, também, à presença de potenciadores de sua absorção, como a vitamina $\mathrm{C}$ e os alimentos de origem animal ou, ao contrário, à presença de inibidores dessa absorção, como os fitatos e outros quelantes de origem vegetal, que podem ser responsáveis pelo estado das reservas marciais. Por outro lado, quando se observa que o fenômeno de espoliação é provocado principalmente por parasitoses intestinais, cuja maior prevalência está na decorrência de deficiências no saneamento ambiental, condição essa típica das áreas habitadas pelas camadas sociais mais baixas.

Estando, assim, as condiçōes gerais para a ocorrência da carência de ferro diretamente ligadas a determinadas formas diferenciais de como as classes sociais se apropriam do produto (bens de consumo) fica evidenciada a relevância, para o conhecimento na área da Saúde Pública, de trabalhos que abordem a questão não como problema centrado no indiví- duo mas na coletividade, de onde se pode recuperar a articulação dos diferentes processos sociais e biológicos em jogo.

MODELO ECONŌMICO E AS DOENÇAS CARENCIAIS: O CASO DA CIDADE DE SÃO PAULO

As ações recíprocas articuladoras dos diferentes niveis de determinação de fenômenos e processos presentes no interior da sociedade e a importância que adquirem para o conhecimento e a prática na área da Saúde Pública podem ser evidenciadas empiricamente, no caso específico da cidade de São Paulo, através de diversos trabalhos que permitem sustentar como as condições de vida nessa cidade apresentam-se como exemplo típico das conexões existentes entre certas doenças carenciais e processos sociais particulares. $8,29,30$

É notório que a pujança econômica de São Paulo em relação a outras áreas do Brasil revela-se tanto pelo tamanho de sua infra-estrutura (sistema de água/esgoto, drenagem, sistema de transporte, edificaçôes de serviços públicos, etc. como por meio de qualquer dos indicadores habitualmente empregados para medir o crescimento econômico (produção industrial, sistema financeiro, renda "per capita", além de outros). No entanto, ao examinar o grau de desenvolvimento da cidade, em função das condições de vida de seus habitantes, o que se observa é um acentuado e crescente desnivel entre as classes so. ciais. Esta diferença, manifestada na opulência de uns poucos e nas dificuldades de muitos, alicerça-se na distância existente entre a riqueza representada pelas moradias suntuosas dos bairros elegantes e a pobreza dos bairros de trabalhadores, carentes dos serviços urbanos básicos como transporte, água, esgoto e habitação. 29,41

Este quadro traçado por Kowarick 29 revela-se em muitos outros trabalhos que analisam a cidade de São Paulo8,29,30. No geral demonstram que, a partir do próprio contraste existente entre o grau de desenvolvimento econômico de São Paulo - medido pelos niveis globais de acumulação - e a presença de situaçōes de pauperismo - exemplificadas pelas condiçōes precárias de saúde, desnutrição e moradia inadequada - é possível colocar em discussão as contradições internas vividas pela metrópole paulistana. Essas contradiçōes, que apontam para as implicações que determinadas condições de vida da população têm, para a geração de problemas de saúde, permitem sustentar o argumento básico de que os problemas típicos de saúde vividos, no caso, pelos estratos baixos da cidade de São Paulo, são re. lativos a uma situação social de subdesenvolvimento e não desaparecem automaticamente com o simples crescimento econômico. 
MARTINS, I.S. et al. As determinações biológica e social da doença: um estudo de anemia ferropriva. Rev. Saúde públ.,

S.Paulo, $21: 73-89,1987$.

Esta questão, que recupera o jogo de açōes e reaçбes existentes sobre a base da "necessidade econômica", evidencia o nível de determinação da instância econômica no desenvolvimento histórico da metrópole paulistana, típico das condições vividas pelos paises do terceiro mundo que se inscrevem no sistema capitalista tardiamente (via processo de in. dustrialização), ou seja, na economia mundial capitalista já constituída. Com isto, pretende-se dizer que o jogo de ações reciprocas presentes entre "necessidade econômica" e "necessidade social" articulam-se, do ponto de vista político, de maneira bastante diferenciada no interior desses países, rela. cionadas às formas de produção e distribuição da riqueza, condicionantes de determinada modalidade de acumulação de capital. Essa especificidade, que recompōe o quadro das relações mantidas pelos homens entre si (relações de classe) e com a natureza (meios de produção), coloca as condições de vida da população paulistana não só submetida ao modo de integração do país no sistema capitalista internacional mas, sobretudo, sua inscrição, numa metrópole com grande expressão dentro da economia brasileira, decorrente do papel que desempenha como espaço privilegiado da inserção do Brasil no mercado internacional, a partir da II Guerra Mundial.

0 tratamento de alguns dos aspectos relevantes desse processo vivido pela cidade de São Paulo pode ser recuperado, em linhas gerais, a partir do trabalho de Kowarick e Campanário30, preocupados com a questão.

O processo de transnacionalização do capital, que começa a se impor no Brasil no período pós guerra, irá encontrar, na cidade de São Paulo, condiçðes concretas para sua realização à medida em que já apresentava um setor nacional produtor de insumos básicos bem desenvolvido, além de mão-de-obra barata e proximidade com amplo mercado consumidor. Como decorrência dessas possibilidades, a cidade passa a concentrar meios de produção e de gerência de grandes empresas multinacionais, estatais e privadas e, consequientemente, a força de trabalho atraída por essa demanda. Submetida aos interesses do capital estrangeiro, a metrópole paulistana torna-se palco de relações estruturais bastante definidas no desenvolvimento dependente associado, com alto custo tanto para o Estado quanto para a classe trabalhadora. Também o Estado, ao emprestar apoio às multinacionais (através de financiamentos diretos, incentivos fiscais, importação de máquinas e equipamentos não produzidos no Brasil), a fim de prover de infra-estrutura o ramo de produção de bens duráveis, passa a sacrificar aqueles setores industriais de consumo de bens não duráveis (notadamente roupas e alimentos) bem como uma série de equipamentos de consumo coletivo, essenciais ao bem estar da população. Considerando que além disso, tal tipo de investimento só pode se realizar através de uma hipertrofia nos gastos públicos, pode-se observar o aumento da pressão inflacionária e criação, ao mesmo tempo, de uma estrutura de distribuição de renda altamente concentrada. 30

Avançando no tratamento do assunto, Kowarick e Campanário30 ainda mostram que a integração da cidade de São Paulo no sistema capitalista internacional, apesar de ter trazido um grande progresso tecnológico à indústria brasileira, gerou grandes contradições, não somente ao aguçar as disparidades regionais em termos de modernização do capitalismo industrial mas, também, ao empobrecer a classe trabalhadora que a própria cidade abriga. Neste particular constatam, por um lado, que o salário mínimo em termos reais diminuiu cerca de $55 \%$ entre 1959 e 1984 , levando o trabalhador a dispensar-por volta de 174 horas de trabalho para conseguir a mesma dieta básica, cuja aquisição exigia pouco mais do que 55 horas de trabalho em 1959. Por outro lado, o custo do terreno aumentou em cerca de $173 \%$ nos últimos 25 anos. Em função disso, o custo da moradia tomou-se inacessível à população de baixa renda, impondo-lhe como uma das poucas alternativas de sobrevivência a periferia da cidade, desprovida daqueles equipamentos coletivos essenciais a um mínimo de habitabilidade ou espaço de vida compatível com a saúde.

E fato notório e amplamente documentado 29 que o trabalhador paulistano gasta, hoje em dia, horas, dentro de um ônibus ou trem, no seu deslocamento de casa ao local de trabalho, além de morar em casas de baixa qualidade técnica, construídas em terrenos muitas vezes inadequados para a implantaçāo de qualquer tipo de edificação. Neste particular o trabalho de Kowarick e Campanário 30 informa que a terça parte da população de São Paulo mora em casas autoconstruidas em zonas distantes desprovidas de serviços básicos. Essa forma de apropriação dos bens de consumo pelas classes apresenta-se ainda mais perversa ao se atentar para a situação relatada por aqueles mesmos autores de que os equipamentos coletivos são subutilizados, na medida em que $42 \%$ das áreas passíveis de edificação encontram-se ociosas, retidas para fins especulativos. Esse quadro é agravado pelo fato de a área periférica vir aumentando ano após ano, concomitantemente à pauperização da classe trabalhadora, área essa que somente nos anos 80 expandiu-se em $480 \mathrm{~km}^{2}$.

A extensão dessa pauperização da classe trabalhadora pode ser melhor evidenciada quando se consideram alguns dados numéricos citados por Kowarick e Campanário 30 que revelam, para 1984, mais de $8 \%$ da população de São Paulo vivendo em favelas e cerca de $20 \%$ em cortiços, ao passu yiu em meados dos anos 70 a estimativa era a de que a cidade 
MARTINS, I.S. et al. As determinações biológica e social da doença: um estudo de anemia ferropriva. Rev. Saúde públ., S.Paulo, 21 : 73-89, 1987.

abrigava $2 \%$ de favelados e $7 \%$ de moradores de cortiços. Outro fato relevante, a partir de 1977 , foi a tendência à escassez de alimentos devida à preferência dada pela política econômica às exportaçóes. Tomando como índice a totalidade dos dados de 1977 , aqueles autores apontam que em 1984 os gê. neros alimentícios atingiram o valor 84 , os produtos de exportação 113 e a cana de açúcar, por sua destinação para fins energéticos, 173.

Em função desse processo, a questão básica a reter, tendo em vista as relaçōes existentes entre processos sociais específicos e doenças carenciais, são as precárias condições de vida da classe operária, historicamente determinadas pelas relaçōes de classe reproduzidas no cenário paulistano nas últimas décadas, dentro de um quadro de miséria e desgaste físico, particularmente agravado nos últimos cinco anos pela recessão econômica. Esse quadro, que reune, portanto, as condições objetivas ao desenca. deamento de processos mórbidos carenciais seria, para usar a terminologia empregada por Laurell32, a representação do "padrão de desgaste e reprodução biológica" criado pela metrópole paulistana e gerador da anemia ferropriva, como doença coletiva.

Considerando que as doenças carenciais apresentar-se-iam, nesse contexto, tanto em função dos processos sociais específicos quanto dos processos biológicos, vistos de maneira inter-relacionada, a questão que se coloca, do ponto de vista epistemológico, é a de como recuperar, a nível da pesquisa empírica, as açoes reciprocas existentes entre ambos os processos. Neste propósito, entende-se que uma tentativa frutífera ao estudo do problema deva contemplar, a nivel da realidade paulistana, grupos populacionais determinados, quer do ponto de vista social, quer do ponto de vista biológico.

\section{A GESTANTE COMO INDIVIDUO VULNERÁVEL A DOENÇA CARENCIAL}

Como se pôde observar, do ponto de vista sociológico, a consideração dos determinantes sociais das doenças carenciais implica necessariamente o estudo das classes sociais que reproduzem os processos geradores das condiçðes objetivas de existência de grupos sociais específicos. Também, do ponto de vista biológico, o estudo dos determinantes dessas carências remete a análise ao conceito de vulnerabilidade orgânica, conceito esse articulador das características definidoras de grupos biológicos específicos frente aos riscos diferenciais de adoecer e morrer por "causas" ou processos mórbidos particulares.

Com relação à anemia ferropriva, a gestante tem sido, do ponto de vista biológico, considerada como indivíduo vulnerável, em função dos processos fisiológicos a que está submetido seu organismo.46,47 Este fato ocorre porque as mulheres, devido à espoliação provocada pelas perdas sangüíneas durante 0 período menstrual, tem maior necessidade de ferro durante o periodo reprodutivo, decorrendo daí sua maior suscetibilidade ao risco de desenvolver anemia. Este risco fica sobremaneira aumentado durante a gestação uma vez que tem sido mostrado agrava. mento da depleção das reservas de ferro da mulher devido não só ao crescimento fetal e placentário como também ao aumento da volemia, próprio da gravidez11,18,21,38,40.

Em função desses processos, as gestantes passam a se constituir, tanto para a clínica obstétrica quanto para a saúde pública, no grupo populacional mais exposto, que outros, ao risco de se tomar ferro-deficiente ou anêmico. Dada a relevância da questão, vários trabalhos da literatura internacional especializada14,15,16,18,19,22,24,25,36,37,39,44,48,52, assim como nacional 1,10,11,13 tem considerado a presença da anemia ferropriva como importante fator de agravamento do risco gravidico, quer para a gestante, quer para o concep to

No entanto, se o conceito de vulnerabilidade orgânica tem sido considerado articulador das características definidoras de grupos biológicos específicos frente aos riscos diferenciais de adoecer e morrer por "causas" ou processos mórbidos particulares, conforme foi assinalado, a questão a ser colocada é a de que essa vulnerabilidade, embora objetivamente expressada ao nível do organismo humano, não se reduz a essa dimensão biológica * ". Restringi.la a esta significa, em outras palavras, descaracterizar-lhe a natureza ao mesmo tempo biológica e social manifestada concretamente, a nível da saúde coletiva dos grupos sociais e biológicos estruturalmente articulados no processo saúde. -doença.

Considerando que a análise das condições de vida da metrópole paulistana sugere questões importantes do ponto de vista da saúde pública, os autores passaram a definir o escopo do presente trabalho tendo

\footnotetext{
- Alguns trabalhos empíricos fornecem dados importantes como, por exemplo, o da OMS 38 que revelou existir, em diferentes pontos do mundo, de 21 a $80 \%$ de gestantes anêmicas e de 40 a $55 \%$ de gestantes ferro-deficientes. Outros trabalhos mostraram que a anemia está associada a um aumento de incidência da toxemia, natimortalidade, abortos e prematuridade 38,39 ; observou-se, igualmente, a ocorrência de maior mortalidade entre gestantes anêmicas 26 . Mais recentemente têm sido publicados trabalhos mostrando uma associação entre anemia materna e baixo peso ao nascer, com o consequiente aumento do risco fetal15,19,24.
}

* A respeito das questões metodológicas envolvidas na análise de risco veja-se, por exemplo, trabalho de Alvarenga 2 . 
MARTINS, I.S. et al. As determinações biológica e social da doença: um estudo de anemia ferropriva. Rev. Saúde públ.,

S.Paulo, $21: 73 \cdot 89,1987$.

em vista o estudo de determinado grupo de gestantes, internamente diferenciado do ponto de vista social, em relação ao risco de exposição, quer à ferro-deficiência, quer à anemia ferropriva.

Para tanto, parte-se do que usualmente se considera, na literatura especializada, como uma situação de carência decorrente de precárias condiçôes sociais e econômicas e representada, no caso, basicamente, pelo baixo consumo do que se convencionou chamar de "bens fundamentais" para a saúde individual e coletiva.

Em função disso, a questão básica sob análise passou a se constituir na do "consumo mínimo" necessário, desses bens, tais como a alimentação e a habitação (esta indicativa das condições de habitat ${ }^{*}$ ), que responderiam, em tese, por um nível crítico de consumo.

Isto equivale a dizer que o processo de deterioração das condições de vida de determinada população, no caso, a de São Paulo, submetida ao "imperativo" do "consumo mínimo" de bens considerados fundamentais, produziria o que se caracteriza por "nível crítico de consumo", isto é, determinada condição de vida abaixo da qual os individuos, no caso as gestantes, adscritas a grupos sociais especificos, estariam inscritos em situaçōes particulares, simultaneamente de naturezas orgânica e social, determinantes dos niveis de risco à doença carencial.

Tendo em vista o objetivo da análise buscou-se aprender elementos da realidade capazes de fornecer subsidios para o estabelecimento de possíveis "niveis críticos de consumo", em função das condiçōes econômica e social da população paulistana, determinantes das condições particulares de dado grupo de gestantes, tomado no presente estudo, como obje to de investigação.

Embora tendo em conta que a explicação das relações existentes, entre situações gerais e particulares, implica a adoção do conceito de classes sociais, as dificuldades presentes para a operacionalização desse conceito, a nível da pesquisa empírica, levou ao emprego de uma perspectiva de estratificação social, tendo em vista a caracterização das condições particulares, sob estudo. Mesmo reconhecendo as limitaçōes teóricas e técnicas impostas ao desenvol. vimento do trabalho, procurou-se explorar, ao máximo, as possibilidades de aproximação, embora reduzidas, que alguns dos indicadores simples (como a renda), ou complexos (como o índice de status socioeconômico) pudessem revelar, com relação à força de determinação geral, que a classe social produz e reproduz na mediação que exerce, entre condições sociais gerais e particulares. Isto, tendo em vista a necessidade de reter, alguns elementos, ao menos indicadores, das condiçōes objetivas de existência da classe trabalhadora, em função das quais emergem as condições para ocorrência da anemia ferropriva, notadamente nos estratos sociais mais baixos.

\section{A ANEMIA E OS NIVEIS CRITICOS DE CONSUMO: ESTUDO DE CASO}

A presente análise refere-se a um grupo de gestantes, de mesma idade gestacional, estratificado segundo o indice de status socioeconômico proposto por Alvarenga e col. ${ }^{3}$, em versão modificada ${ }^{*}$, em função do qual foi observado o estado de estoques marciais. A população estudada foi constituída de uma amostra de 145 mulheres, assim distribuidas: 74 gestantes com 36 semanas ou mais de gestação, escolhidas por amostragem casual dentre aquelas atendidas regularmente no Centro de Saúde "Geraldo Paula Souza", no período compreendido entre $01 / 07 / 77$ a 30/06/78, 71 gestantes que receberam atendimento pré-natal na Maternidade Amparo Maternal, cujo parto (36 semanas ou mais de gestação) ocorreu entre 01/04/78 e 15/05/ 78. A presente amostra, da qual foram excluídas as gestantes que apresentaram doenças próprias ou associadas à gravidez, é parte de um amplo levantamento sobre as condições nutricionais da gestante, e foi descrita por Siqueira 47. O estado dos estoques marciais foi analisado através das medidas da concentração de hemoglobina, hematócrito, ferro sérico e capacidade total de ligação de ferro no sangue. As

\footnotetext{
*Entende-se, por "habitat" o espaço físico de vida, determinado pela condição de classe que atrela às condições de habitação, condições de saneamento compatíveis ou não com condiçôes desejáveis de saúde de uma determinada população ou segmento de população.

- O referido Índice ${ }^{3}$, composto por quatro variáveis-ocupação do marido ou responsável pela família, renda por pessoa da famnlia, escolaridade do marido e da mulher - obteve na amostra em questâo, para as referidas variáveis, respectivamente, os seguintes pesos $(0,62)(0,79)(0,74)(0,74)$, calculados a partir da correlação $(r)$ de Pearson. As amplitudes dos estratos ou camadas sociais foram obtidas segundo critério teórico, diferente, portanto, daquele utilizado no trabalho original, por parecer representar uma melhor aproximação da situação particular considerada com as situações econômica e social características da metrópole paulistana. Nesse sentido, o sistema de estratificação da população analisada teve, com base nos escores obtidos, a seguinte variação para cada estrato social: baixo (escores de 2,89 a 7,71 ), médio baixo (escores de 7,72 a 12,54), médio (escores de 12,55 a 17,37), médio al to (escores de 17,38 a 22,20 ) e al to (escores de 22,21 a 27,04 ).
} 
MARTINS, I.S. et al. As determinações biológica e social da doença: um estudo de anemia ferropriva. Rev. Saúde públ., S.Paulo, $21: 73-89,1987$.

gestantes definidas como "ferro-deficientes" foram aquelas que apresentaram ferro sérico abaixo de $90 \mathrm{mg} / \mathrm{dl}$, saturação de transferrina abaixo de $25 \%$ e capacidade total de ligação de ferro acima de $360 \mu \mathrm{g} / \mathrm{dl}$, mantendo normais os níveis de hemoglobina. Foram consideradas "anêmicas" as gestantes que apresentaram, também, os níveis de hemoglobina abaixo de $11 \mathrm{~g} / \mathrm{dl}$ e de hematócrito abaixo de $35 \% 4,23,43,51$.
A Tabela 1 apresenta a trajetória observada entre as condiçōes de normalidade e de anemia, em termos de processo, cuja fase intermediária entre a doença manifesta e o estado de normalidade é representada pela deficiência de ferro sem anemia, entendida como fase subclínica. Nesta, esses três momentos do processo são representados, em função das condições socioeconômicas do grupo consi. derado.

\section{TABELA 1}

Número e percentagem de gestantes normais, ferro-deficientes e anêmicas, segundo estrato social. São Paulo, 1977/78.

\begin{tabular}{|c|c|c|c|c|c|c|c|c|c|}
\hline \multirow{3}{*}{$\begin{array}{c}\text { Estrato } \\
\text { social }\end{array}$} & \multicolumn{7}{|c|}{ Carência de ferro } & \multirow{2}{*}{\multicolumn{2}{|c|}{ Total }} \\
\hline & \multicolumn{2}{|c|}{ Normais } & \multicolumn{2}{|c|}{ Ferro-deficientes } & & \multicolumn{2}{|c|}{ Anêmicas } & & \\
\hline & No & $\%$ & Nọ & $\%$ & _ & Nọ & $\%$ & No & $\%$ \\
\hline Baixo & 7 & 24,1 & 10 & 34,5 & & 12 & 41,4 & 29 & 100,0 \\
\hline Médio-baixo & 49 & 54,4 & 26 & 28,9 & & 15 & 16,7 & 90 & 100,0 \\
\hline Médio & 14 & 60,9 & 7 & 38,4 & & 2 & 8,7 & 23 & 100,0 \\
\hline Médio-al to & 2 & 66,7 & - & - & & 1 & 33,3 & 3 & 100,0 \\
\hline Alto & - & - & - & - & & - & - & - & - \\
\hline
\end{tabular}

$\mathrm{Na}$ Tabela 1 constata-se que quanto mais alto o estrato social, maior a proporção de gestantes normais e menor a proporção de gestantes anêmicas. Apesar dos estratos médio-alto e alto terem apresentado valores pouco representativos, essas categorias foram mantidas para se poder contar, por hipótese, com um sistema de estratificação mais próximo às condiçбes sociais e econômicas da população pertencente à metrópole paulistana* .

Esse processo "saúde-doença", observado de maneira característica para o estrato social baixo, onde das 29 mulheres $24,1 \%$ são normais, $34,5 \%$ são ferro-deficientes e $41,4 \%$ são anêmicas, não apresenta a mesma tendência para os demais estratos. Como se pode notar, principalmente nos estratos médio-baixo e médio, a tendência se inverte, uma vez que mais de $50 \%(54,4 \%$ para o primeiro e $60,9 \%$ para o segundo, respectivamente) das gestantes são normais, do ponto de vista da anemia carencial.

Embora a "precisão" do instrumental utilizado para a definiçđo dos estratos sociais possa ser ques- tionada, em função da complexidade que medidas dessa natureza geram do ponto de vista da pesquisa empírica, o fato é que muitos outros elementos entram em jogo na análise da questão. Um deles seria, inclusive, a própria atuação dos serviços de saúde que poderiam, através da assistência pré- natal, interferir na ocorrência do processo carencial com intensidades diferentes de acordo com a freqüência ao serviço e a qualidade da assistência. Assim, pode-se supor que gestantes pertencentes a estratos diferentes utilizam o serviço de maneira distinta e característica.

Vale considerar que nesse tipo de ação de saúde é possível pensar, quer no próprio fornecimento de vitaminas (prática bastante usual em alguns serviços de pré-natal), quer na atividade educativa desses serviços quanto à orientação alimentar capaz de permitir à gestante das classes médias (e mesmo das baixas) uma suplementação de ferro à sua dieta, em função de modificação proposta, passível de ser pensada, em diferentes graus, no interior do mesmo orçamento doméstico.

\footnotetext{
- Vale ressaltar, no entanto, que a variável renda por pessoa da família interferiu nessa busca de aproximação pelo fato de a amplitude da escala utilizada circunscrever-se, de acordo com a proposta metodológica dos autores, aos dados empíricos da população amostral analisada. Isso significa que, embora a escala recupere, no extremo inferior, rendas mais baixas por pessoa da família isso não ocorre para o extremo superior, em função da população amostral que não $^{3}$ por hipótese, abarcam todas as possibilidades empíricas, conforme pode ser ooservado no trabalho original ${ }^{3}$. Na presente amostra a escala de renda por pessoa da familia utilizada compreendeu as seguintes categorias, definidas em função da distribuição empírica: $1(0 \vdash 1 / 4) ; 2(1 / 4 \vdash 2 / 4) ; 3(2 / 4 \vdash 3 / 4) ; 4(3 / 4 \vdash 1) ; 5(1 \vdash 11 / 2) ; 6(11 / 2$ $\vdash 2) ; 7(2 \vdash 3) ; 8(3 \vdash 4) ; 9(4 \longmapsto 5) ; 10(5 \mathrm{e}+)$ salários mínimos.
} 
MARTINS, I.S. et al. As determinações biológica e social da doença: um estudo de anemia ferropriva. Rev. Saúde públ., S.Paulo, $21: 73-89,1987$.

Aceitar esse tipo de interpretação implica em reconhecer que, no presente caso, a questão da explicação causal apresenta-se muito mais complexa do que é usualmente considerada. Com isto se quer dizer que fica evidente que além de uma condição biológica que favorece, no caso da gestante, o desenvolvimento da carência de ferro, esta condição é não só reproduzida, mas também modificada pelas condições estruturais, ou seja, por processos gerais e específicos que se articulam em diferentes níveis no interior da sociedade brasileira.

E nesse sentido que se inscrevem como importan. tes para a análise da anemia ferropriva, por exemplo, as condiçōes deficientes de saneamento básico que, mediante maior prevalência de parasitoses intestinais provocam maior espoliação de ferro, ou ainda, a alimentação deficiente em proteina de origem animal e vitamina $C$, que gera dificuldades à absorção do ferro alimentar.
Se alguns desses fatos podem revelar processos mais gerais, característicos do próprio estilo de vida da maioria dos brasileiros, a questao fundamental a considerar é que a especificidade da explicação para doenças carenciais somente pode ser encontrada em função das possibilidades diferenciais de condições objetivas de existência que caracterizam o nivel em que se dá o poder de compra dos bens fundamentais para a manutenção das condiçб̃es de saúde individual e coletiva.

Buscando avançar na análise do processo de instalação da carência de ferro, sugerida pela Tabela 1 , foram construídas duas outras com o propósito de responder a algumas das indagações já levantadas.

A Tabela 2 permite mostrar a relação apresentada entre os estratos sociais e a doença carencial, consideradas globalmente nas mulheres ferro-deficientes e anêmicas.

TABELA 2

Número e percentagem de gestantes, normais e com carência de ferro, segundo estrato social. São Paulo, 1977/78.

\begin{tabular}{lrrrrrr}
\hline \multirow{2}{*}{$\begin{array}{c}\text { Estrato } \\
\text { social }\end{array}$} & \multicolumn{9}{c}{ Carência de ferro } \\
\cline { 2 - 7 } & Normais & $\%$ & \multicolumn{2}{c}{$\begin{array}{c}\text { Ferro-deficientes/ } \\
\text { anêmicas }\end{array}$} \\
\hline Baixo & 7 & 24,1 & No & $\%$ & Total \\
Médio-baixo & 49 & 54,4 & 22 & 75,9 & 29 & 100,0 \\
Médio & 14 & 60,9 & 41 & 45,9 & 90 & 100,0 \\
\hline
\end{tabular}

$$
\begin{array}{rll}
X^{2} & \text { para estrato baixo e médio-baixo } & =8,1 \\
X^{2} & \text { para estrato baixo e médio } & =7,2 \\
X^{2} & \text { para estrato médio-baixo e médio }= & 0,31 \\
\alpha & =0,05 \\
X^{2} & \text { crítico }=3,84
\end{array}
$$

Pela análise da Tabela 2 , observa-se uma diferença quanto à proporção de mulheres normais ou carentes nos diferentes estratos sociais. Assim, o estrato baixo apresenta diferenças estatisticamente significantes quando confrontado, seja com o estrato médio-baixo ou médio, no que diz respeito às proporções de "carentes" ou normais. Já os estratos médio-baixo e médio não apresentam, entre si, diferenças estatisticamente significantes.

Este resultado permite duas colocações: em primeiro lugar, situa o estrato baixo como aquele que discrimina a possibilidade de as mulheres a ele pertencentes conseguirem manter uma higidez. Este fato melhor se evidencia quando se considera que enquanto no estrato baixo apenas uma mulher em cada quatro pode ser considerada normal, mais da metade das gestantes dos estratos medio-baixo e médio sáo normais. Nesses termos, o estrato baixo poderia ser considerado como "estrato crítico" para a existência da carência de ferro, numa demonstração de que a anemia carencial da gestação é um problema de "classe social". A segunda colocação é a de que, mesmo reconhecendo que pela Tabela 1 as proporções de gestantes ferro-deficientes têm valores próximos nos três grupos de estratos sociais, ainda assim o problema não deve ser encarado como de caráter puramente biológico ou independente da "situação de classe". Isto porque, apesar do tamanho da amostra, ao se reunirem gestantes anêmicas 
MARTINS, I.S. et al. As determinações biológica e social da doença: um estudo de anemia ferropriva. Rev. Saúde públ.,

S.Paulo, 21 : 73-89, 1987.

com gestantes ferro-deficientes (Tabela 2), pôde-se observar diferenças significantes entre as camadas sociais, o que permite supor o estrato baixo como o mais exposto ao risco da carência de ferro, fato este bastante importante, uma vez que pode representar um aumento do risco, com repercussões para o crescimento e desenvolvimento intra e extra-uterino do concepto.

$\mathrm{Na}$ medida em que os dados não revelaram diferenças entre os estratos médio-baixo e médio, devido provavelmente ao pequeno número de casos, pro. curou-se, na Tabela 3 , classificar as mulheres em dois grupos, estrato baixo e demais estratos, visando analisar o comportamento dos estoques marciais em termos do processo da enfermidade *

Como se pode verificar na Tabela 3, a proporção de anêmicas foi maior no estrato baixo $(41,4 \%$ dos casos) contra $15,5 \%$ nos demais estratos agrupados. 0 fato a considerar é que, mesmo com a significância do teste $X^{2}$ da Tabela 3 , a ferro-deficiência pareceu apresentar maior homogeneidade entre os três estratos.

TABELA 3

Número e percentagem de gestantes normais, ferro-deficientes e anêmicas, no estrato baixo e nos demais agrupados. São Paulo, 1977/78.

\begin{tabular}{|c|c|c|c|c|c|c|c|c|}
\hline \multirow{3}{*}{$\begin{array}{l}\text { Estrato } \\
\text { social }\end{array}$} & \multicolumn{6}{|c|}{ Carência de ferro } & \multirow{2}{*}{\multicolumn{2}{|c|}{ Total }} \\
\hline & \multicolumn{2}{|c|}{ Normais } & \multicolumn{2}{|c|}{ Ferro-deficiente } & \multicolumn{2}{|c|}{ Anêmicas } & & \\
\hline & Nọ & $\%$ & No & $\%$ & Nọ & $\%$ & Nọ & $\%$ \\
\hline Baixo & 7 & 24,1 & 10 & 41,4 & 12 & 41,4 & 29 & 100,0 \\
\hline $\begin{array}{l}\text { Médio-baixo + } \\
\text { Médio + médio } \\
\text { Alto }\end{array}$ & 65 & 56,0 & 33 & 28,4 & 18 & 15,5 & 116 & 100,0 \\
\hline
\end{tabular}

$$
\begin{array}{llr}
\mathrm{X}^{2} & \text { para anêmica e ferro-deficiente } & =2,36 \\
\mathrm{X}^{2} & \text { para anêmica e normal } & = \\
\mathrm{X}^{2} & \text { para normal e ferro-deficiente } & = \\
\alpha & 3,92 \\
\alpha & 0,05 \\
\mathrm{X}^{2} & \text { crítico }=3,84
\end{array}
$$

Em função desses resultados obtidos, algumas hipóteses podem ser sugeridas, em termos explicativos. Uma delas é a de que a anemia não-manifesta (ferro-deficiência) seria mais estreitamente relacionada aos processos biológicos (decorrentes das condições orgânicas e fisiológicas geradas pela gravidez), que à "classe social", o que reduziria a explicação da doença carencial, nessa fase, o nível do enfoque biológico. Tendo em vista que o mesmo não acontece com a fase terminal dessa carência e que, por hipótese, esses dois momentos são etapas de um processo tanto de natureza biológica quanto social, a questão a destacar é que muitos elementos entram em jogo para a explicação do fenômeno, principal. mente nessa fase intermediária. É o caso já citado da própria atuação dos serviços de saúde. Em função disso acredita-se poder sustentar que, em termos explicativos, a análise das questóes acima envolve necessariamente a consideração das condiçoes estruturais gerais da sociedade brasileira que geram determinados processos, tais como determinados hábitos alimentares observados segundo as classes no interior da sociedade inclusiva, ou determinado nível da assistência à saúde da mulher e da criança, articuladores de determinadas situaçōes presentes no processo saúde-doença. Por outro lado, aspecto importante a considerar é que o próprio sistema de estratificação adotado permanece como questão em aberto, do ponto de vista da pesquisa empírica, dada sobretudo a complexidade existente no estabelecimento dos limites dos estratos, o que pode significar a inclusão indevida de mulheres normais, ferro-deficientes ou mesmo anêmicas, nos diferentes estratos sociais determinados.

Tendo em vista que um fato marcante que persiste nas diferentes composições dos dados apresentados (Tabelas 1, 2 e 3) é o de que o estrato baixo evidencia o caráter social da doença carencial, em termos de um processo típico, sua contrapartida biológica apresenta-se no fato de se poder pensar que a esse estrato se associa uma alta prevalência de * Os autores reconhecem que, assim procedendo, a aplicaçāo do $\mathrm{X}^{2}$, para comparaçōes internas, acarretou uma diminui-
ção do erro que passou para 0,0125 , englobando as três comparaçóes. 
MARTINS, I.S. et al. As determinaçōes biológica e social da doença: um estudo de anemia ferropriva. Rev. Saúde públ.,

S.Paulo, $21: 73-89,1987$.

mulheres carentes de ferro, incapazes de manter seu estoque marcial em função dos processos biológicos e fisiológicos típicos das condiçōes de gravidez. Neste particular, a hipótese básica de que se parte é a de que as mulheres pertencentes ao estrato baixo estão mais expostas ao risco da anemia ferropriva que as dos demais estratos, por não terem acesso aos "bens fundamentais mínimos", necessários para a manutenção dos estoques marciais numa situação de gravidez, situação essa típica, do ponto de vista biológico. Dentre os "bens fundamentais" que concorrem para a explicação dos niveis de determinação das doenças carenciais, duas condições particulares foram consideradas essenciais para a análise do processo, quais sejam, uma dieta adequada qualitativa e quantitativamente e condiçбes adequadas de habitat. Tendo em vista a análise dessas questões, algumas definições teóricas e instrumentos metodológicos específicos foram incorporados ao presente estudo.

Para o tratamento da dieta, definiu-se como "fundamental" um conjunto de alimentos, veículos de energia e nutrientes, capazes de caracterizar uma "dieta mínima" para uma famnlia de tipo 4 pessoas". Essa "dieta mínima", foi elaborada levando-se em conta a famnlia média padrão de área metropolitana, os hábitos alimentares da população, assim como a necessidade da dieta, além desta conter um aporte quantitativamente satisfatório de ferro, propiciar condiçōes de aproveitamento desse ferro de origem animal (carnes) e vitamina $\mathrm{C}$, que favorece a absorção.

A Tabela 4 é uma representação de um "modelo ideal" dessa dieta mínima e baseou-se em trabalho de Martins 34 seguindo recomendação da FAO/OMS/ ONU28. Esse tipo de modelo, apesar dos problemas metodológicos que pode apresentar, a nível de pesquisa empírica serve, como recurso de análise para se poder avaliar, embora de uma maneira aproxima. da, o custo do "bem fundamental" - "dieta adequada".

Para a análise do caso de gestantes, houve a necessidade de se elaborar um modelo específico de dieta que atendesse às peculiaridades próprias da gravidez, o qual se encontra representado na Tabela 5 , de acordo com a metodologia FAO/OMS/ONU28.

Com base na Tabela 5 , pôde-se calcular as necessidades de alimentos, fornecedores de energia e nutrientes para a familia média padrão paulistana considerada.

A partir da caracterização dessas necessidades pôde-se calcular o custo dessa dieta a preços de mercado, de acordo com os alimentos componentes da mesma. Segundo os preços vigentes em fevereiro de 1982, estimou-se que o custo da dieta seria correspondente a 1,3 salários mínimos. No mês de dezembro de 1985. o custo dessa mesma dieta correspondeu a essa mesma quantia, ou seja, de 1,3 salários mínimos.

No que se refere às condições de habitação favo. ráveis à manutenção da saúde, foram tomados como critérios a noção de "moradia minimamente adequada" assim como o seu custo. Branco5 (1980) preocupado com a questão aponta a impossibilidade da política habitacional, então vigente, atender às necessidades de uma moradia que atendesse a esse requisito, sem comprometer o orçamento destinado àquelas necessidades básicas, como alimentação $\mathrm{e}$ transporte. Dentro dos sistemas PROMORAR e COHAB, uma família típica de São Paulo (de 5 pessoas) cơm menos de 7 salários mínimos, limite de renda para ser atendida pelo programa, dificilmente disporia, segundo esse autor, de excedentes satisfatórios ao atendimento de necessidades básicas (alimentação, transporte, vestuário, higiene, saúde, educação, lazer, e outras). Seria, segundo ele, necessário estabelecer o quantum dos diversos orçamentos típicos, para se chegar à quantia possivel a ser destinada à moradia. Dadas as implicaçōes estruturais da questão, a postura "ideal", para uma política habitacional seria, de acordo com Branco5, a de se estabelecer as condições de pagamento da moradia a partir da análise do poder aquisitivo global do orçamento familiar, ou seja, através do excedente obtido pela dedução dos gastos mais essenciais da renda total da famnlia. A nível operacional, frente a essas limitações concretas decorrentes das condições objetivas de existência da classe trabalhadora, a premissa básica seria, no caso, a de permitir o acesso a moradias "minimamente adequadas" com o menor comprometimento possível do orçamento destinado às necessidades básicas. Ainda em relação ao assunto, - autor revela que as normas estabelecidas pelo Banco Nacional da Habitação (BNH), através da política habitacional que criou os programas habitacionais de interesse social (COHABs e INOCOOPs), além de representarem uma oferta insignificante frente às necessidades, não atendiam (e não atendem) às premissas em que se fundamentaram, segundo as quais não mais do que $20 \%$ do orçamento familiar deveria ser destinado ao pagamento da moradia. Constata que a maior parte da população carente gastava mais do que a quinta parte da sua renda familiar em habitação, sendo que o contingente com renda familiar entre 1,75 e 2,00 salários mínimos teria uma capacidade aquisitiva para a mo-

- A tipologia apresentada pela família de 4 pessoas foi adotada por corresponder ao número médio de pessoas por família da área metropolitana de São Paulo em 198017 . Essa famılia seria constituída por um homem de idade entre 20 e 39 anos, uma mulher gestante de idade entre 20 e 39 anos, uma criança em idade escolar, entre 7 e 9 anos e outra em idade pré-escolar, en tre 4 e 6 anos. 


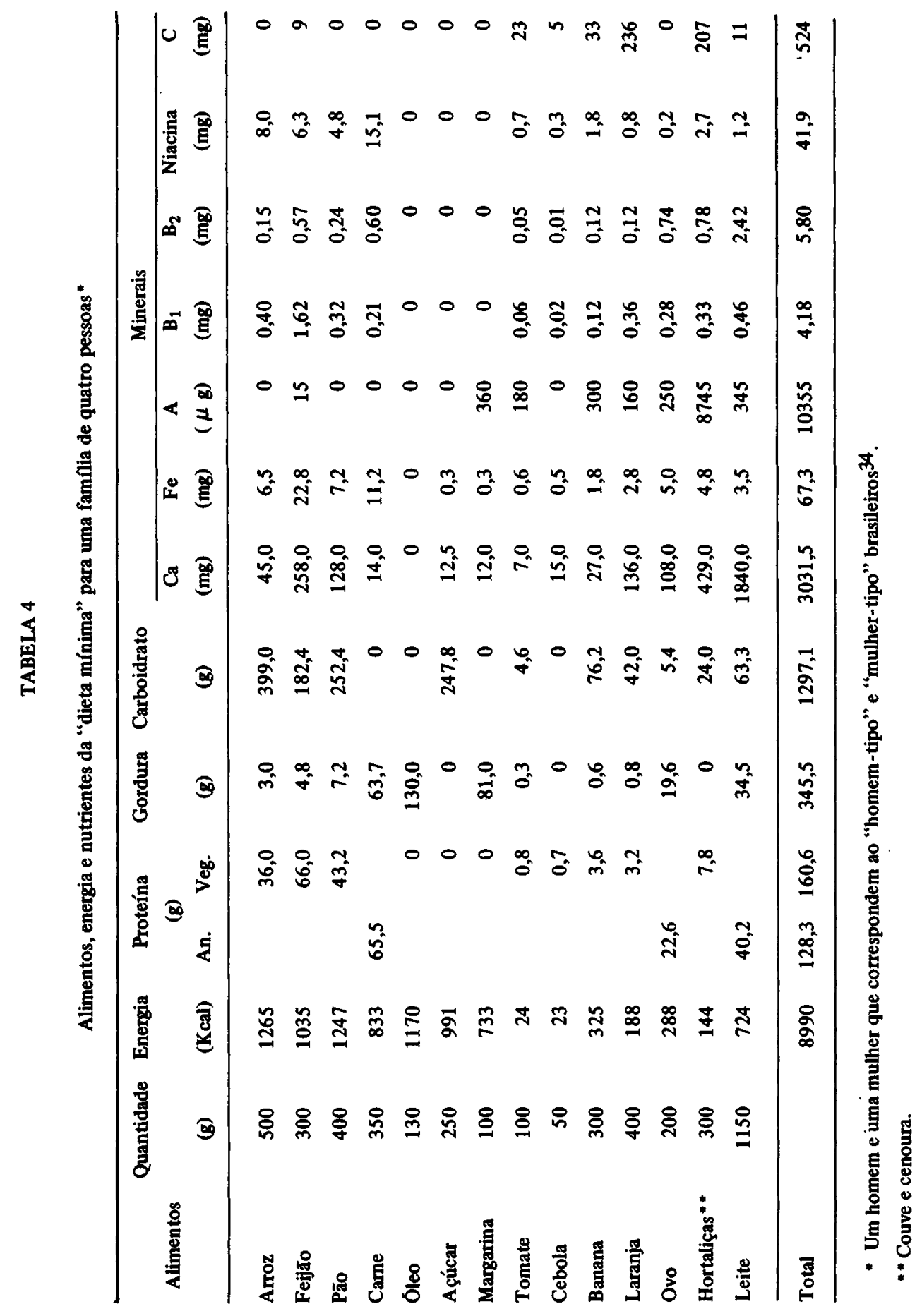




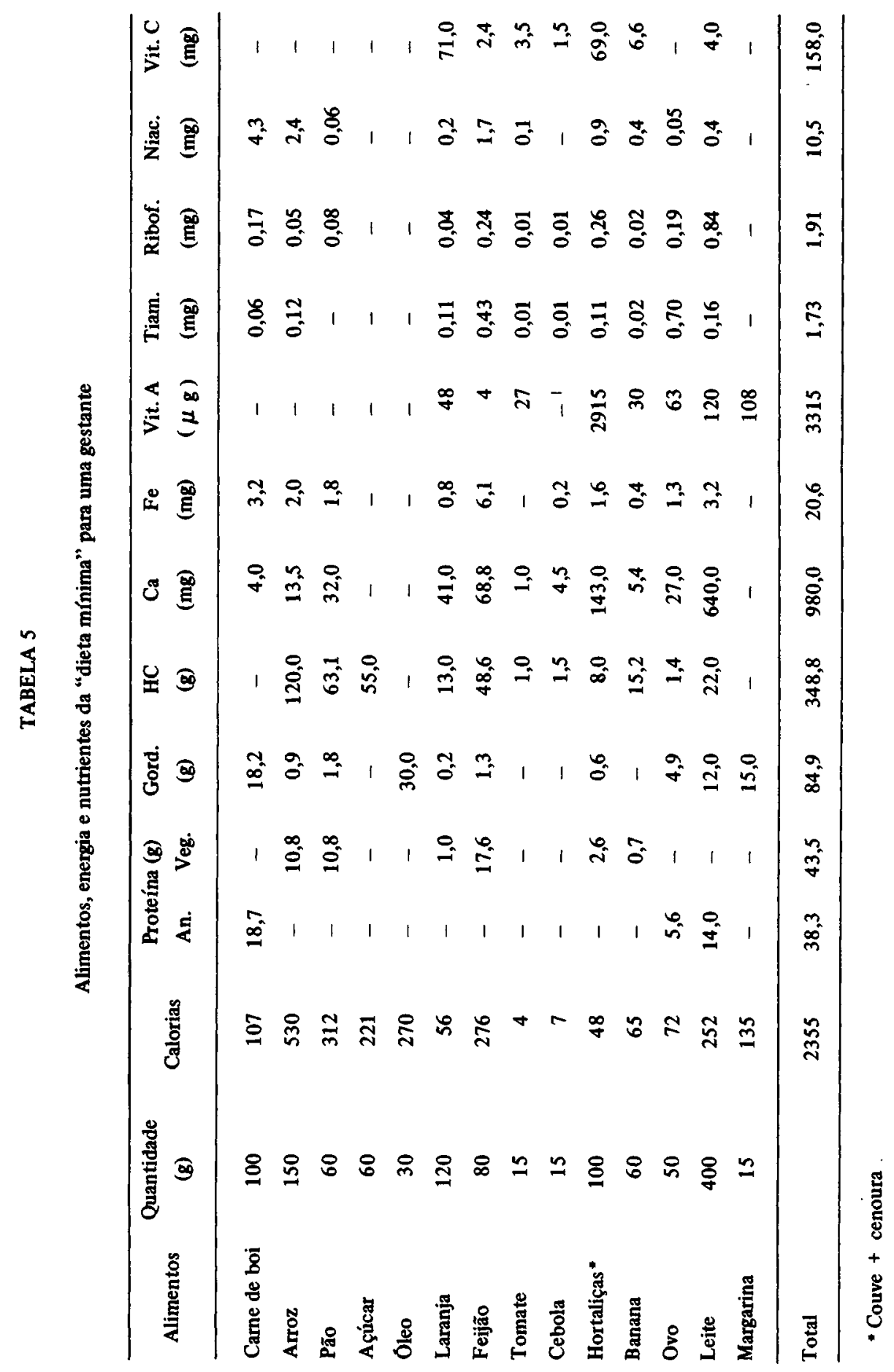


radia igual a zero e aqueles entre 2,25 e 2,75 salários mínimos, de menos de $10 \%$ do orçamento da família.

Tendo em vista que as condições de moradia são consideradas, no presente trabalho, como parte dos "bens fundamentais" necessários para se prevenir um aumento do risco de adquirir a anemia ferropriva, sua relação com as condições de saneamento sáo evidentes pelas possibilidades de agravamento desse risco 35 . Buscando analisar a questão do padrão minimo de moradia, respeitados os próprios padrōes culturais, esta deveria conter, segundo Branco5, $36 \mathrm{~m}^{2}$ *. E condição necessária que a mesma deva fazer parte de um meio ambiente onde não faltem os recursos sanitários mínimos tais como água enca. nada e tratada, além de um sistema de esgoto. A partir das normas" * do Sistema Financeiro de Habitação, o preço final de uma habitação dentro desses requisitos era de 750 UPC, em 1982 montante esse que pelas normas daquele Sistema acarretava em fevereiro do mesmo ano um gasto mensal de um salário mínimo. Em dezembro de 1985 o custo mensal de uma moradia de $760^{\circ}$ UPC passou a acarretar um gasto mensal de 0,66 salários mínimos **

Na Tabela 6 verifica-se os percentuais do orçamento familiar gastos na alimentação e habitação, por categoria sócio-profissional do chefe de famnlia nas regióes metropolitanas, levantados no Estudo Nacional da Despesa Familiar (ENDEF)17, de 1975.

TABELA 6

Percentual das despesas correntes da familia destinados à alimentação e habitação, por categoria sócio-profissional do chefe da familia, nas regióes metropolitanas - 1975.

\begin{tabular}{lcccc}
\hline Cargos & $\begin{array}{c}\text { Cargos de } \\
\text { nével superior }\end{array}$ & $\begin{array}{c}\text { Cargos de } \\
\text { nível médio }\end{array}$ & Outras Ocupações \\
\hline Despesas correntes & $100 \%$ & $100 \%$ & $100 \%$ & não manuais \\
Alimentação & $13 \%$ & $18 \%$ & $28 \%$ & $100 \%$ \\
Habitação & $38 \%$ & $36 \%$ & $32 \%$ & $36 \%$ \\
Outros & $49 \%$ & $46 \%$ & $40 \%$ & $30 \%$ \\
\hline
\end{tabular}

Fonte: Fundação IBGE17.

Por não se contar com dados mais recentes, lançou-se mão desse estudo visando o aprofundamento da análise. Considerando que a população pertencente à classe trabalhadora esteja possivelmente incluída pela classificação apresentada na Tabela, na categoria "outras ocupaçōes", o fato a observar é a tendência apresentada de aumento do percentual em despesas com alimentação e uma diminuição nos gastos com habitação; se esse perfil de despesas tiver se mantido até o presente, esses dados sugerem que esses setores da população devem estar procurando formas de moradia incompativeis com um mínimo de bem-estar, tais como as favelas, cortiços e outros. Ademais, com base na análise realizada para o caso de São Paulo, é possível supor que essa tendência representa as próprias condiçóes objetivas de vida da classe trabalhadora, na medida em que a restrição dos gastos recaj, ao que parece, na habitação. Pela lógica do sistema, esta classe procura soluções com. pativeis com seus rendimentos, ou seja, nas áreas da periferia, com toda a problemática de saneamento básico já apresentada.

Pela Tabela 6 observa-se que mais de $60 \%$ do orçamento familiar da categoria "outras ocupações" seriam destinados à alimentação e moradia o que exigiria, por pessoa da família, cerca de um salário mínimo em 1982, e 0,79 em 1985, para que a "família padrão" alcançasse as condições mínimas para a aquisição dos "bens fundamentais" necessários à prevenção da anemia ferropriva.

A Tabela 7 apresenta a distribuição das categorias de renda por estrato social na população estudada. Esta Tabela permite observar a posição da população amostral na época da coleta de dados, segundo o "estrato", em função dos rendimentos mínimos que deveria ter para a aquisição dos "bens fundamentais" à manutenção das condiçōes de higidez que hipoteticamente poderiam ter evitado a anemia contraída.

\footnotetext{
- Informação pessoal.

- R/BNH n?s 06/79; 24/79; 73/80 e 106/81. 


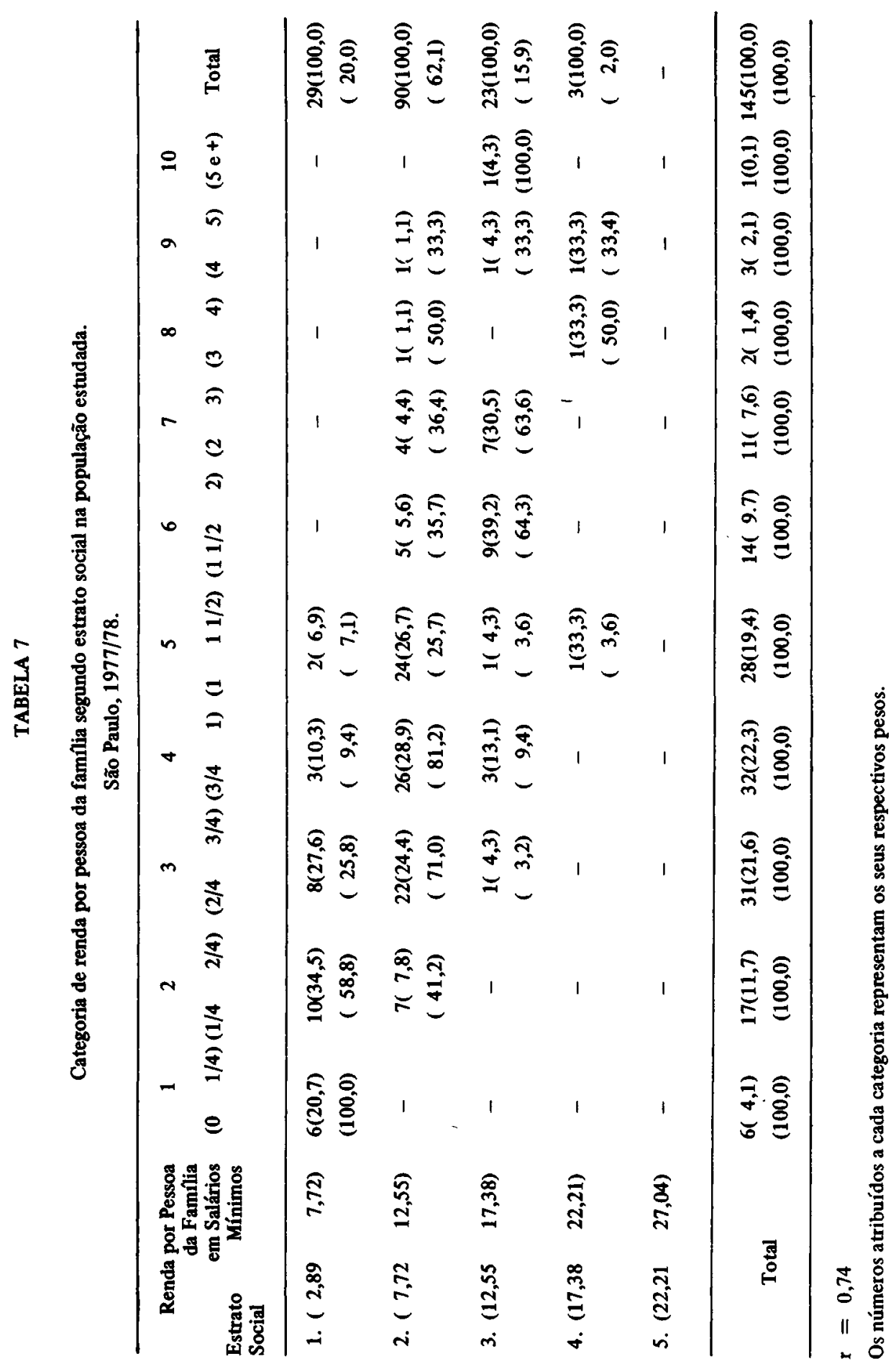


MARTINS, I.S. et al. As determinações biológica e social da doença: um estudo de anemia ferropriva. Rev. Saúde públ., S.Paulo, 21 : 73-89, 1987.

0 que se depreende é que os valores mais freqüentes de renda localizam-se nas categorias 4 e 5 para $\circ$ estrato médio-baixo. Considerando que as possibilidades de compra desses bens implicavam, por hipótese, a presença de uma renda de 1,0 e 0,79 salários mínimos por pessoa da familia, em 1982 e 1985, respectivamente, isso sugere que as famnlias das categorias de renda quatro e menos, ou seja, cerca de $60 \%$ da população amostral não teriam as condições mínimas para a aquisição desses "bens fundamentais". Assim, somente cerca de $40 \%$ da população do estrato médio-baixo da amostra poderiam, teoricamente, adquirir esses "bens fundamentais" mínimos".

Esta constatação tem relevância quando é cotejada com a distribuição dos dados observados nas Ta. belas 1,2 e 3 , com relação ao processo "normalidade - carência de ferro", e se observa que $45,6 \%$ das gestantes do estrato médio-baixo (Tabela 2) apresentaram alguma das formas dessa carência.

Esta relação, que destaca o nivel de participação da renda familiar na definição das possíveis condições objetivas de existência da classe trabalhadora, é reforçada quando se observa que somente $7,1 \%$ da categoria quatro de renda (Tabela 7) se localizam a nível do estrato baixo. Este fato apresenta interesse quando se nota que somente $9,7 \%$ das mulheres normais localizaram-se no mesmo estrato.

Tendo em vista que, em função da Tabela 7, o estrato médio-baixo apresenta alta percentagem de categorias de renda $(60,0 \%)$ incompatíveis com as possibilidades objetivas de aquisição dos "bens fundamentais" considerados mínimos e, na medida em que cerca de $80,0 \%$ da população amostral localiza. se nos dois primeiros estratos, a hipótese que se levanta é a de que essas condições mínimas de existência somente seriam possiveis, em termos gerais, a partir do estrato médio propriamente dito. Esta não contraria, mas confirma a tendência geral observada na análise do caso de São Paulo. $O$ que se depreende é que este fato estaria mostrando, a nivel do particular, a insuficiência do poder aquisitivo da classe trabalhadora, decorrente dos processos gerais da sociedade. Em função disso, seria no interior dessa classe (em seus estratos mais baixos) que a anemia ferropriva teria, por hipótese, maior probabilidade de incidência, considerados os vários processos em jogo, quer de natureza social, quer de natureza biológica.

Considerada a importância da apreensão dos níveis de relações existentes entre processos gerais e processos específicos na definição dos diferentes aspectos particulares do processo saúde-doença presentes na saúde coletiva, a questão que permanece em aberto é a da relevância da busca de instrumentais teórico-metodológicos capazes de dar conta, na pesquisa empírica, dos diferentes níveis de determinação em jogo.

Dados os problemas de natureza metodológica (tanto teóricos quanto técnicos), presentes nessa questão, o desafio que se coloca para o avanço nessa área de conhecimento diz respeito, sobretudo, à mensuração das classes sociais enquanto elemento articulador de uma totalidade social. Isto, na medida em que, pelas suas especificidades, somente este tipo de conceito pode dar conta das relaçōes existentes nos processos reais, determinantes da saúde e da doença.

Nesse sentido, a questão a colocar é que a adoção de propostas de estratificação social, como aqui foi empregada, no sentido de estabelecer algumas relações entre situaçōes particulares e situações globais, devem ser consideradas limitadas, do ponto de vista teórico, ou seja, servem como aproximações grosseiras das verdadeiras condições de classe existentes no interior de formaçōes sociais concretas. Embora re- conhecendo que o emprego desse tipo de instrumental não atenderia à necessidade de explicação das relações presentes no processo saúde-doença da "anemia ferropriva", como de fato se apresenta a a nível da realidade social (paulistana), $o$ significado de sua adoção, para definir as condiçōes sociais e econômicas de uma determinada amostra de gestantes em particular, foi o de poder não só apontar mas também reafirmar o fato de que as determinaçбes de classe, definidas a nível geral, manifestam sua presença, a nível do particular, revelando-se, inclusive, a partir de indicadores simples como a renda, a ocupação e a escolaridade. Dai, as condições de classe serem, portanto, determinaçōes que se im. põem, reproduzindo e mediando condiçб̆es gerais e particulares de vida.

0 fato é especialmente importante quando se considera a relação teoria e prática no campo da saúde pública. Isto porque, em termos institucionais, o campo da Saúde Pública tem tradicionalmente alicerçado suas propostas de intervenção num tipo de conhecimento que privilegia, senão reduz, a explicação do processo saúde-doença, a uma simples determinação biológica, centrada a nível do organismo humano, o que necessariamente circunscreve e limita as possibilidades concretas de "solução" do problema, quando não as escamoteiam.

\footnotetext{
- Convém ressaltar que essa análise superestimou o poder de compra dessa população, uma vez que não se incluiu, por exemplo, o custo do transporte na estimativa dos "bens fundamentais".
} 
MARTINS, I.S. et al. As determinaçōes biológica e social da doença: um estudo de anemia ferropriva. Rev. Saúde públ., S.Paulo, $21: 73 \cdot 89,1987$.

MARTINS, I.S. et al. [The biological and social determinants of illness - a study of iron-deficiency]. Rev.Saúde públ., S.Paulo, $21: 73-89,1987$.

ABSTRACT: An attempt was made to distinguish the various levels of determination of deficiency anemia, as a public health phenomenon, on the basis of the biological and social relationships which define this health-disease process. By correlating the analysis of the specific processes of a sample population of pregnant women to the general processes characteristic of life in Greater São Paulo (Brazil), to which city the sample population belong, it was possible to observe how the conditions which lead to the occurrence of iron-deficiency anemia are linked to the social and economic conditions characteristic of the particular class contexts to which individuals are related, be it by qualitative and quantitative dietary deficiences, or by the poor conditions of environmental health, these factors typical of the areas inhabited by the lower social strata. In view of the singular biological processes involved and in order to bring into focus another hierarchical level of these determinations, the analysis of these deficiencies was applied to the concept of organic vulnerability, a concept taken as the concatenator of the distinguishing characteristics of specific biological groups in view of the differential risks of falling ill and dying through particular "causes" or processes leading to death, risks which are linked to the very conditions under which the social classes live. By characterizing the ultimate determining causes of iron-deficiency anemia on the basis of the low level of consumption of what the authors have decided to call "basic necessities", the analysis sought to identify characteristic elements of living standards in the city of São Paulo, capable of providing data of the establishment of possible "critical levels of consumption", that is to say, of a particular living standard below which individuals, in this case pregnant women, separated into specific social groups, would be ascribed to particular situations, simultaneously of antorganic and social nature, "determinative" of levels of risk with regard to deficiency disease. The case study focused on the existing course between normal and anemic conditions, in terms of process, the intermediate phase of which, between the diseased and the normal states, was represented by non-anemic iron-deficiency, understood as a sub-clinical phase. In this phase, the three moments of the process were analysed, as a function of the socioeconomic conditions of the group under consideration. By constituting categories, in the light of the analytical process, in terms of income, as incompatible with the objective possibilities of the acquisition of defined minimum "basic necessities", the authors have succeeded in characterizing a particular social and economic condition below which the iron-deficiency anemia would, hypothetically, be more likely to occur, taking into consideration the various processes involved, whether of a social or a biological nature.

UNITERMS: Health and disease. Anemia, hypochromic, occurrence. Pregnancy. Socioeconomic factors. Social class. Diet. Urban sanitation. Risk.

\section{REFERÊNCIAS BIBLIOGRĀFICAS}

1. ALMEIDA, P.A.M. de et al. Indentificação e avaliação dos fatores clínicos da gestação de alto risco. Rev. Saúde públ., S.Paulo, 9:417-25, 1975.

2. ALVARENGA, A.T. de 0 conceito de risco na área matemo-infantil: considerações teóricas, metodológicas e de aplicação. São Paulo, 1984. [Tese de Doutorado - Faculdade de Saúde Pública da USP].

3. ALVARENGA, A.T. de et al. Indice de status socioeconômico da família da mulher grávida que frequienta o Centro de Saúde Geraldo de Paula Souza da Faculdade de Saúde Pública da Universidade de São Paulo. Rev.Saúde públ., S.Paulo, $7: 351-67$, 1973.

4. BOTHWELL, T.H. \& MALLET, B. The determination of iron in plasma or serum. Biochem. J., 59:599. $.602,1955$.

5. BRANCO, M.P.P. Capacidade de pagamento. [s.1.p.], 1980. [mimeografado].

6. BREILH, J. Epidemiologia: economia - medicina y politica. 2a. ed. Santo Domingo, Secretaria de Estado de Salud Publica y Asistencia Social, 1980.

7. BREILH, J. \& GRANDA, E. Investigacion de salud en la sociedad: guia pedagógico sobre un nuevo enfoque del método epidemiológico. Quito, Ediciones C.E.A.S., 1980.

8. CAMARGO, C.P.F. de et al. Sáo Paulo 1975: cresci. mento e pobreza. São Paulo, Ed. Loyola, 1975.

9. DEVI, P.K. Observations on anemia in pregnancy in India. Isreel J. med. Sci., 2:494-8, 1966.
10. CIARI JR., C. \& ALMEIDA, P.A.M. de Elementos de avaliação do risco gravídico. Rev. Saúde públ., S.Paulo, 6:361-70, 1972.

11. CIARI JR., C. \& SIQUEIRA, A.A. F. de Problemas de saúde materno-infantil no Brasil. In: Pareta, J.M.M. et al. Saúde da comunidade: temas de medicina preventiva e social. São Paulo, McGraw-Hill do Brasil, 1976. p. 203-23.

12. CHOPPRA, J.G. \& BYAM, N.T.A. Anemia survey in Trinidad and Tobago. Amer. J. publ. Hlth, 58 : 1922-36, 1968.

13. DELASCIO, D. \& ALMEIDA, P.A.M. de Propedêutica da gestação de alto risco. São Paulo, Livraria Manole, 1974.

14. DONAHUE JR., C. \& WAN, T.T.H. Measuring obstetric risks of prematurity: a preliminary analysis of neonatal death. Amer. J. Obstet. Gynec., 116:911-5, 1973.

15. DONNELLY, J.F. et al. Maternal, fetal and environmental factors in prematurity. Amer. J. Obstet. Gy. nec., 88:636-44, 1960.

16. EDWARDS, L.E. et al. A simplified antepartum risk - scoring system. Obstet. Gynecol., 54 : 237-40, 1975.

17. FUNDAÇĀO IBGE. Despesa familiar. Anu. estat. Brosil, Rio de Janeiro, $41: 677-720,1980$.

18. GILES, C. \& BURTON, H. Observation on prevention and diagnosis of anemia in pregnancy. Brit.med.J., 2:636-44, 1960 . 
MARTINS, I.S. et al. As determinações biológica e social da doença: um estudo de anemia ferropriva. Rev. Saúde públ., S.Paulo, $21: 73-89,1987$.

19. GOLD, M.E. et al. Identification of high-risk fetus. Amer.J.publ.Hlth, 59:1851-6, 1969.

20. GOOSEN, C.J. Anaemias of pregnancy in Africans. J.Obstet. Gynaec. Brit.Emp., 68:994-9, 1961.

21. GREBE, G. et al. Correlación entre la deficiencia de hierro y la ingesta dietetica de hierro en el embarazo. Rev. med.Chile, 107: 989-92, 1979.

22. HAERI, A.D. et al. A scoring system for identifying pregnant patients with high risk of perinatal mortality. J.Obstet. Gynec. Brit. Cwlth, 81 : 535-8, 1974.

23. HERBERT, V. Drugs effective in iron deficiency and other hypochromic anaemias. In: Goodman, L.S. \& Gilman, A., eds. Pharmacological basis of therapeutics. $3^{\text {rd }}$ ed. New York, MacMillan, 1965. p. $1394-442$.

24. HERNANDEZ, C.E.R. et al. Embarazzo de alto riesgo 1a. Identificacion del alto riesgo prenatal y su repercusion en el recien nascido. Ginec. Obstet.Mex. 45 : 379-81, 1975 .

25. HOBEL, C.J. et al. Prenatal and interpartum high-risk screening. Amer.J.Obstet. Gynecol., 117 $1-9,1973$.

26. INTERNATIONAL NUTRITIONAL ANEMIA CONSULTIVE GROUP. Guidelines for the eradication of iron deficiency; report., Göteborg, Sweden, 1977.

27. JOHNSON, A.A. et al. The prevalence and the etiology of the nutritional anemias in Guyana. Amer.J. clin. Nutr., $35: 309-18,1982$.

28. JOINT FAO/WHO/ONU EXPERT CONSULTATION ON ENERGY AND PROTEIN REQUIREMENTS, Rome, 1981. Report. Geneva, World Health Organization, 1985. (WHO - Techn. Rep. Ser., 724).

29. KOWARICK, L. $A$ espoliaçāo urbana. Rio de Janeiro, Paz e Terra, 1979.

30. KOWARICK, L. \& CAMPANÄRIO, M. São Paulo: metrópole do subdesenvolvimento industrializado. $\mathrm{No}$ vos Est. CEBRAP, 13:67-73, 1985.

31. LAURELL, A.C. Medicina y capitalismo en México. México, Ediciones Era, 1975. p. 80-93. (Cuardernos Políticos 5).

32. LAURELL, A.C. La salud - enfermedad como proceso social. Cuad.méd. soc., Rosário, 19:7-20, 1982.

33. MARGO, G. et al. Anemia in urban underprivileged children. Iron, folate, and vitamin $\mathrm{B}_{12}$ nutrition. Amer.J.clin.Nutr., 30:947-54, 1977.

34. MARTINS. I.S. \& PEREZ HIDALGO, C. Recomendação de energia e nutrientes para a população brasileira. Brasília, Instituto Nacional de Alimentação e Nutrição, 1983. [Mimeografado].

35. MASPES, V. \& TAMIGAKI, M. Importância da reabsorção do ferro provocada pela ação dos vermes na progressão da anemia. Rev. Saúde públ., S.Paulo, 13: $357.67,1979$.

36. MERCIER, G.E. \& DESJARDINS, P.D. Evaluation numérique du risque pendant la grossesse. Union med. Can., $102: 102-6,1973$.

37. NESBITT JR., R.E.L. \& AUBRY, R.H. High risk obstetrics. II - Value of semi objective grading system in identifying the vulnerable group. Amer.J.Obstet. Gynec., $103: 972-85,1969$.
38. ORGANIZAÇÃO MUNDIAL DA SAƯdE. Expert Committee on the Prevention of Perinatal Mortality and Morbidity, Geneva, 1969. Report. Geneva, 1970. (WHO-Techn. Rep. Ser., 457).

39. ORGANIZAÇĀO MUNDIAL DA SAUDE. Risk approach for maternal and child health care. Geneva, 1978. (WHO - Off -set Publ., 39).

40. PERKIN, G.W. Assessment of reproductive risk in nonpregnant women. Amer.J.Obstet. Ginec., 101 : $709-17,1968$.

41. PREFEITURA DO MUNICÍPIO DE SÃO PAULO. Coordenadoria Geral do Planejamento. Sistema Municipal de Informação e Documentação. Saneamento básico: água e esgoto. São Paulo, 1981. (Boletim n? 1).

42. REUNION MIXTA ADI/OIEA/OMS, Ginebra, 1970. Lucha contra la anemia nutricional, especialmente contra la carencia de hierro; informe. Ginebra, Organización Mundial de la Salud, 1975. (OMS - Ser. Inf. tecn., 580).

43. SCHADE, A.L. et al. Bound iron and unsaturated ironbinding of serum, rapid and realiable quantitative determination. Proc. Soc. exp. Biol., New York, 87 : $443 \cdot 8,1954$.

44. SEPTIEN, J.M.C. Estudio y evaluacion del riesgo maternofetal antes del parto. Ginec. Obstet. Méx., 40 : $221 \cdot 30,1975$.

45. SIMMONS, K.W. et al. Nutritional anemia in the Englishspeaking Caribbean and Suriname. Amer.J. clin. Nutr., $35: 327-37,1982$.

46. SIQUEIRA, A.A.F. de Mortalidade neo-natal e premituridade. São Paulo, 1974. [Dissertação de Mestrado - Faculdade de Saúde Pública da USP].

47. SIQUEIRA, A.A.F. de Estudo de um conjunto de curvas antropométricas no diagnóstico de estado nutricional de gestantes e sua relação com o tamanho do recém-nascido. São Paulo, 1979. [Tese de Doutorado - Faculdade de Saúde Pública da USP].

48. SOKOL, R.J. et al. Clinical application of high risk scoring on an obstetric service. Amer. J. Obstet. Gynec., 128:652-61, 1977.

49. SZARFARC, S.C. Anemia ferropriva em parturientes e recém-nascidos. Rev. Saúde públ., S.Paulo, $8: 369$ 74,1974

50. SZARFARC, S.C. Anemia nutricional entre gestantes atendidas em Centros de Saúde do Estado de São Paulo (Brasil). Rev. Saúde públ., S.Paulo, 19:450-7, 1985.

51. VENTURA, F. et al. Hemoglobina: dosagem pelo método da cianometahemoglobina. Uso de solução artificial para a calibração dos aparelhos colorimétricos. Rev.Hosp.Clin.Fac.Med., S.Paulo, 22 : 303-4, 1967.

52. ZACUTTI, A. et al. La gravidanza ad al to rischio. Minerva ginecol., 24 : 150-62, 1972.

Recebido para publicaçāo em 18/07/1986

Reapresentado em 11/12/1986

Aprovado para publicação em 15/12/1986 